\title{
Introduction: Narendra Modi and India's foreign policy
}

\author{
Ian Hall ${ }^{1}\left[\right.$. Šumit Ganguly ${ }^{2}$
}

Accepted: 13 October 2021 / Published online: 30 October 2021

(c) The Author(s), under exclusive licence to Springer Nature Limited 2021

\begin{abstract}
This article introduces the special issue on Narendra Modi and India's foreign policy. It observes that there is little consensus about the effectiveness of the Modi government's management of international relations. Some argue that since it first came to power in May 2014 it has transformed India's foreign policy and proved far more successful than its predecessors in handling the country's key relationships and challenges. Others contend that India's basic strategy is unchanged and that New Delhi's position is weaker today in important areas, notably regarding China and Pakistan than it was under earlier regimes. This article introduces this debate and the analytical questions addressed in the special issue concerning the extent of prime ministerial autonomy in foreign policymaking, the role of ideas and ideology, and the question of how far India's agency is constrained by structural impediments, both in its immediate region and further afield.
\end{abstract}

Keywords India $\cdot$ Narendra Modi $\cdot$ Indian foreign policy $\cdot$ Hindu nationalism

\section{Introduction}

Few Indian prime ministers-with the clear exception of the first, Jawaharlal Nehru-have prompted as intense and sustained a debate about their foreign policy as Narendra Modi. ${ }^{1}$ In part, this is due to the energy he and his Bharatiya Janata

\footnotetext{
${ }^{1}$ See especially Chatterjee Miller and Sullivan de Estrada (2017), Chaulia (2016), Ganguly (2017), Gokhale (2017), Gupta et al. (2019), Hall (2019), Karnad (2018), Mohan (2015), Pant (2019), Singh (2017), Tremblay and Kapur (2017). This special issue is the product of a roundtable that was meant to be held at the International Studies Association Convention in 2020. We would like to thank the contributors for persisting with the project despite the cancellation of the Convention and the journal's editors and reviewers.
}

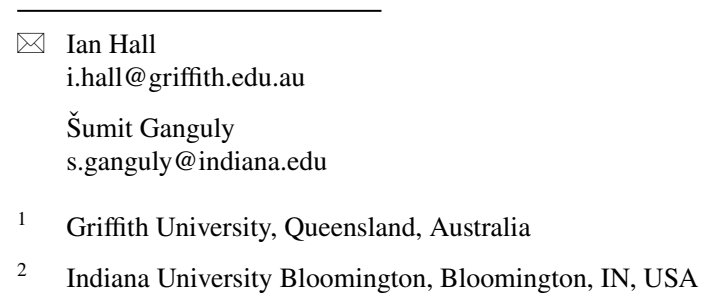


Party-led government brought to the conduct of international relations after their first landslide win in the May 2014 general election (Ganguly 2017: 140). In contrast to his predecessor, Manmohan Singh, Modi proved a very enthusiastic traveller, embarking on as many foreign visits during his first term in office as Singh did in a decade, attending a series of high-profile summits, and aiming to establish rapport with his counterparts in China, Japan, and the United States, as well as in South Asia. His government also revamped key initiatives-such as 'Look East', rendered into 'Act East' - and launched others, including a renewed effort to build better ties with India's neighbours, branded 'Neighbourhood First'. It promised to play a major role in providing security and improving infrastructure in the Indian Ocean region, as well as to enhance its defence and diplomatic ties with states stretching from the Middle East through Central and South Asia to Southeast Asia. Significantly, the Modi government also pledged to reground Indian foreign policy in a set of principles more in tune with what it views as India's traditions, and to restore its standing in the world, ensuring its status and interests are respected by all, including major powers like the United States or China.

Whether Modi and his ministers have achieved these objectives or will achieve them with the policies they have put in place are keenly contested questions. Some argue that the Modi government has revolutionised as well as energised foreign policy, boosted national pride and the country's 'soft power' in the world, strengthened relationships with key partners, and restored the standing of India in the world, as well as the confidence of foreign investors. The 'Modi government's foreign policy has been transformative', one study concluded, and Modi 'has established himself' as both 'a world leader' and a 'policy entrepreneur' (Tremblay and Kapur 2017: $218-219 ; 15) .^{2}$ His 'open embrace' of a strategic partnership with the United States has been praised as both far-sighted and prudent (George 2018; cf. Pant and Joshi 2017) and his handling of an increasingly assertive China cast as deft (Gokhale 2017: 111-140). In parallel, his government's responses to terrorist attacks across Kashmir's Line of Control-including a punitive raid by Indian special forces and an air strike into Pakistan proper-have been praised for their strength and their supposed deterrent effects on Islamabad (Gokhale 2017).

Others are less complimentary. A number of analysts argue that Modi and his ministers have changed less than might at first appear. For them, the basic strategy and overall 'trajectory', Rajesh Basrur put it, of Indian foreign policy is largely 'unchanged' (Basrur 2017). ${ }^{3}$ Some suggest that the Modi government's claims to have broken from long-standing ways of thinking about or practicing foreign policy are unconvincing (Hall 2019). Many question its management of key relationships and challenges. They argue that since 2014 the US-India partnership has not progressed as far and as fast as it might and that even when the disruptive effects of Donald J. Trump are taken into account, the Modi government bears a significant

\footnotetext{
2 Other sympathetic assessments, varying in their enthusiasm, include Abhyankar (2018), Chaulia (2016), Gokhale (2017), Mohan (2015), and Pant (2019).

${ }^{3}$ For similar arguments, see Ganguly (2017), Hall (2015, 2016), Karnad (2018), Ogden (2018), Singh (2017).
} 
amount of responsibility for those failings (Tellis 2018). The administration's handling of relations with China and Pakistan has been subjected to even more sustained criticism, even if his various critics disagree on the exact source of the problem (see, for example, Bajpai 2017; Karnad 2018). Modi has been assailed for being too confrontational with China, to India's detriment (Jha 2017), and at the same time, criticised for being too deferential to its President, Xi Jinping (Tharoor 2018: 450-455). His government's efforts to diplomatically isolate Pakistan over its alleged backing of terrorism have found more support, but doubt remains in some minds about India is more or less secure as a result of its punitive raids across the Line of Control and its heavy-handedness in Kashmir (Mazumdar 2017). ${ }^{4}$ Similarly, Modi's efforts to strengthen ties with India's South Asian neighbours and like-minded states in the wider Indo-Pacific region have received very mixed assessments (Rajagopalan 2020).

\section{Analysing Indian foreign policy}

This special issue does not aim to settle these disputes. Rather, it explores the underlying drivers of India's foreign policy under the Modi government and tests some of the assumptions that underpin judgements of its performance. One of the biggest of these, of course, is the idea that Modi himself is a transformational leader bringing about major changes in both domestic and foreign policy. ${ }^{5}$ This is an idea that he and his supporters are keen to promote, but one which demands rigorous assessment. It is often assumed that Indian prime ministers have unusually broad latitude in foreign policymaking compared to other democratic leaders, due to the centralisation of control within the core executive and low levels of both parliamentary and public interest in the area. ${ }^{6}$ This has led to a persistent tendency in the literature to explain shifts in foreign policy, as well as successes and failures, in terms of what leaders think and do. And it suggests that if Modi did have a transformational agenda for Indian foreign policy, he might be able to put it into practice.

However, recent studies argue that this focus on leaders has repeatedly produced misleading explanations of India's behaviour in international relations, overemphasising their capacity to determine what is done at the expense of other factors, such as contestation between different parts of the central government (see Hansel et al. 2017; Friedrichs 2019). This directs attention away from the prime minister himself, and towards their ministers and advisors, and the bureaucrats that work for them, shaping and implementing policy, as well as party political differences. Others argue that in foreign policy as in domestic policy, bargaining between New Delhi and India's States and Union Territories, and between

\footnotetext{
${ }^{4}$ For a short discussion of the effort to isolate Pakistan, see Jaffrelot (2017: 30-32).

5 On this concept and for an analysis of the claim that Modi is a 'transformational leader' focused on domestic politics, see Chhibber and Verma (2018: 135-150). See also the literature on Modi as an authoritarian populist: Chacko (2018), Plagemann and Destradi (2019), Wojczewski (2020).

6 For a classic account, see Bandyopadhyaya (1970).
} 
the central government and other powerful actors within the country, including the big industrial conglomerates or agricultural interests, can also restrain the core executive and limit the choices it can make (see Mattoo and Jacob 2010). In what follows, we can see both of these sets of limitations in operation, at certain moments, in the case of the Modi administration.

Another set of assumptions addressed in this special issue concerns the roles of ideas and ideology. The Modi government has put significant effort into changing the language of Indian foreign policy, setting aside terms and concepts inherited from the postcolonial era dominated by Jawaharlal Nehru, and introducing new ones largely drawn from the Hindu nationalist tradition of thought, running back to Swami Vivekananda and Aurobindo Ghose (Hall 2019). Modi's supporters argue that this reimagining or reinvention of India's international relations is freeing the country to play a bigger role in the world and opening up new opportunities for global leadership (Chaulia 2016). But whether these attempts have been successful is unclear, and it remains a moot point whether under Modi Indian foreign policy is guided by Hindu nationalist thinking. A number of scholars argue that it continues to be shaped by inherited ideas, which fits with earlier research that points to the stability over time of elite attitudes in India about foreign policy (see Ganguly et al. 2017). Others observe that the Modi government's approach, like those of earlier administrations, is also marked by incrementalism and pragmatism (see Basrur 2019; Chatterjee Miller 2020).

The third set of assumptions concerns agency and structure in the international system. Some think that India's choices are constrained because its material power is still relatively low and because the context in which the Modi government has found itself has been and remains challenging (see Pant and Rej 2018; Tellis 2016). They argue as a consequence that even a leader that aspires to be transformational and to cast foreign policy in a new language will struggle to bring about substantive change. Aside from the state of Indian economy, which has not improved as fast as Modi promised back in 2014, the biggest external constraint is, of course, China. The People's Republic's rapid economic development under Deng Xiaoping and his successors began to be perceived as a significant problem for India in the 1990s, posing as it continues to do a combined political, economic, and security challenge. China's development model offers a potent alternative to India's less dynamic but arguably more legitimate approach. Its sheer weight-which is still growing - is changing both the bilateral relationship and India's immediate region, as fast-changing patterns of trade and investment affect its neighbours. And its military modernisation, combined with its uncertain intentions, raises the possibility of conflict across an unsettled border.

The Modi government was perhaps unfortunate to come to power soon after $\mathrm{Xi}$ Jinping's ascent to paramountcy in 2013 and doubly unfortunate to be in power during Donald J. Trump's presidency, from 2017 to 2021. Its agency was limited by these two developments, which led to far more assertive behaviour by Beijing and more capricious behaviour by Washington, at least until Joseph R. Biden's inauguration as President of the United States. Tensions and troubles with both China and US complicated India's relationships with its immediate neighbours, especially Nepal, Pakistan, and Sri Lanka (see Jacob, in this special issue). At the same time, however, 
as some of the articles in this issue show, shared concerns about Beijing and Washington also prompted New Delhi to deepen ties with other partners, including Australia, Japan, and a number of East Asian and West Asian states.

In sum, this special issue aims to dig deeper into the underpinnings of the Modi government's foreign policy and to try to explain why its approach has taken the form that it has since it first came to office in May 2014. It aims also to account for both the successes and the failures of an administration that has had to wrestle with a slowing economy and an increasingly difficult international climate exacerbated by the onset of the Covid-19 pandemic in early 2020.

\section{The articles}

The articles that follow explore the management of key relationships by the Modi government or its handling of important areas of foreign and security policy. The first four examine India's relations with the United States, China, Japan, and Australia. Šumit Ganguly argues that Modi has had a significant impact on US-India ties, first in setting aside any grievance he might have had about an earlier ban on entering the US imposed upon him, and then in investing effort in building personal relationships with Barack H. Obama and then Donald J. Trump. He observes too that the Modi government's shift away from nonalignment and the pursuit of strategic autonomy, a tempering of anti-Americanism within the BJP, and the Trump administration's disregard for human rights issues smoothed the road to closer ties, despite missteps by both sides and tensions over trade. He argues, however, that the principal reason for the improvement of ties was shared concern about Beijing's increasingly assertive behaviour across the region.

In his contribution, Manjeet Singh Pardesi looks at India's vexed relations with China during Modi's time in office. He observes the complexity of the bilateral relationship, shaped by a mix of memory, status anxiety, conflicting interests, and unresolved differences. He notes too that, like its predecessors, the Modi government has employed a combination of both internal and external balancing, accommodation, and competition to manage the rivalry with China. He argues that its particular mix has been heavier on external balancing-principally by deepening the strategic partnership with the US and other 'like-minded' states in the Indo-Pacific-but that the pressure generated by China's economic growth has made the management of the bilateral relationship more difficult. He concludes by suggesting that both Beijing and New Delhi will need to find ways to accommodate each other's interests if they are to avoid further tensions or even military clashes, like the incident that left dozens of troops dead in the Galwan Valley in Ladakh in June 2020.

The third article turns to India's changing relationship with Japan. Rajesh Basrur and Sumitha Narayanan Kutty trace the origins and the substance of the partnership between the two-now dubbed a 'special strategic and global partnership'. They observe the congruence of India's Look East/Act East policy and Japan's vision of a 'Free and Open Indo-Pacific' and the efforts made to build formalised dialogue mechanisms and encourage defence and security cooperation between the two. They also outline the extent of the Japanese public and private investment in India, 
including in major infrastructure projects, as Tokyo aims to boost India's medium to long-term economic prospects. They also explore the burgeoning of minilateral coordination and cooperation beyond the bilateral partnership, including under the auspices of the Quadrilateral Security Dialogue (or 'Quad'), which draws in Australia and the US.

Ian Hall's contribution explores another of India's strategic partnerships: its developing, but asymmetrical relationship with Australia. He notes that the election of the Modi government and his visit to Australia six months later-the first by an Indian prime minister since 1986-raised hopes in Canberra that fast progress would be made both in extending defence and security ties and in negotiating a free trade agreement. He argues, however, that those hopes were not realised, despite mounting worries in both capitals about China's ambitions and assertiveness. Progress was steady but unspectacular on the security side of the partnership, with greater dialogue and more meaningful exercises between the two militaries. But the talks for a free trade deal stalled, and then New Delhi walked away too from the Regional Economic Comprehensive Partnership negotiation process, which aims at lowering barriers to trade across East Asia. In part, these troubles were a product of leadership instability in Canberra, but Hall argues they also suggest institutional shortcomings in New Delhi, as the Modi government found it hard to translate political will into substantive change.

The next two articles analyse the Modi government's management of India's relations with the states and regional institutions of two key regions: South Asia and the Middle East (or, as New Delhi prefers, West Asia). Happymon Jacob assesses the Modi government's approach to India's immediate region. He argues that Hindu nationalist ideology has played a significant role in shaping the way in which it has conducted relations with some of the key states. He notes too that despite the accommodating rhetoric initially used by Modi and his ministers, New Delhi has sometimes taken a straightforwardly aggressive line with some of its neighbours. He explores too the linkages between domestic politics and foreign policy, concerning Kashmir and India's citizenship laws, on the one hand, and electoral imperatives at the centre and in India's border states. And he dissects the ways in which China's growing economic and diplomatic influence in South Asia is affecting New Delhi's ties with each of its neighbours.

Nicolas Blarel turns next to India's shifting relationships with the states of West Asia, an area in which it is clear that Modi and his government have brought about some significant change. New Delhi has deepened a security partnership with Israel — and brought it out of the shadows, not least with a prime ministerial visit. Modi has also invested heavily in personal diplomacy with a number of Gulf States, including Saudi Arabia and the United Arab Emirates, seeking investment funds, better protections for the Indian diaspora in the region, and shoring up access to oil supplies. Throughout, the Modi government has also been concerned to advance its long-running effort to loosen the ties that some of these states have to Pakistan, as it seeks to isolate Islamabad over its support for terrorist groups operating from its territory.

The final two articles deal with crucial issues, rather than relationships: India's evolving foreign economic policy and its changing place in the global nuclear order.

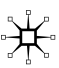


Amrita Narlikar sets out the broad outlines of the Modi government's approach to the global economy, focussing especially on its dealings with the World Trade Organisation. She observes continuities with the ways in which earlier administrations have managed foreign economic policy, despite the introduction of schemes like 'Make in India' and the Atmanirbhar Bharat Abhiyan (Self-Reliant India Campaign) rolled out since the 2019 election. Narlikar argues that although the Modi government has been more protectionist than some expected it might be, this approach may be better suited to a global economy increasingly characterised by 'weaponised interdependence'.

In the last paper, Rajesh Rajagopalan examines the Modi government's nuclear policy, including its management of India's nuclear arsenal, its nuclear doctrine, and its nuclear diplomacy. He argues that here too there has been less change and more continuity than might have been expected, given the BJP's insistence that it is taking a more robust approach to national security and its hints that it might move India away from the 'No First Use' doctrine it has had since the weapons tests in 1998. He argues too that, on the face of it, these policy continuities are odd, since India faces two potential nuclear adversaries - China and Pakistan - that are both in the process of expanding and modernising their arsenals and using unconventional means, including incursions by troops and proxies, to exert pressure on New Delhi.

\section{Declarations}

Conflict of interest On behalf of all authors, the corresponding author states that there is no conflict of interest.

\section{References}

Abhyankar, R.M. 2018. Indian Diplomacy: Beyond Strategic Autonomy. New Delhi: Oxford University Press.

Bajpai, K. 2017. Narendra Modi's Pakistan and China policy: assertive bilateral diplomacy, active coalitiondiplomacy. International Affairs 93 (1): 69-92.

Bandyopadhyaya, J. 1970. The Making of India's Foreign Policy: Determinants, Institutions, Processes and Personalities. Bombay: Allied Publishers.

Basrur, R. 2017. Modi's Foreign Policy Fundamentals: A Trajectory Unchanged. International Affairs 93 (1): 7-26.

Basrur, R. 2019. Modi, Hindutva, and Foreign Policy. International Studies Perspectives 20(1): 7-11.

Chacko, P. 2018. The Right Turn in India: Authoritarianism, Populism and Neoliberalisation. Journal of Contemporary Asia 48(4): 541-565.

Chatterjee Miller, M. 2020. Do Leader Ideologies Influence Foreign Policy? Nehruvianism vs. Moditiva. Asia Policy 27(2): 176-178.

Chatterjee Miller, M., and K. Sullivan de Estrada. 2017. India's Rise at 70 (Special Issue). International Affairs 93(1): 1-219.

Chaulia, S. 2016. Modi Doctrine: The Foreign Policy of India's Prime Minister. New Delhi: Bloomsbury.

Chhibber, P.K., and R. Verma. 2018. Ideology and Identity: The Changing Party Systems of India. New York: Oxford University Press.

Friedrichs, G. 2019. From Factions to Factions: India's Foreign Policy Roles Across Different Party Systems. India Review 18(2): 125-160. 
Ganguly, S. 2017. Has Modi Truly Changed India's Foreign Policy? The Washington Quarterly 40(2): $131-143$.

Ganguly, S., T. Hellwig, and W.R. Thompson. 2017. The Foreign Policy Attitudes of Indian Elites: Variance, Structure, and Common Denominators. Foreign Policy Analysis 13(2): 416-438.

George, V.K. 2018. Open Embrace: India-US Ties in the Age of Modi and Trump. New Delhi: Penguin.

Gokhale, N. 2017. Securing India the Modi Way: Pathankot. New Delhi: Bloomsbury.

Gupta, S., R.D. Mullen, R. Basrur, I. Hall, N. Blarel, M.S. Pardesi, and S. Ganguly. 2019. Indian Foreign Policy under Modi: A New Brand or Just Repackaging? International Studies Perspectives 20(1): $1-45$.

Hall, I. 2015. Is a 'Modi Doctrine' Emerging in Indian Foreign Policy? Australian Journal of International Affairs 69(5): 247-252.

Hall, I. 2016. Multialignment and Indian Foreign Policy under Narendra Modi. The Round Table. The Commonwealth Journal of International Affairs 105(3): 271-286.

Hall, I. 2019. Modi and the Reinvention of Indian Foreign Policy. Bristol: Bristol University Press.

Hansel, M., R. Khan, and M. Levaillant, eds. 2017. Theorizing Indian Foreign Policy. London and New York: Routledge.

Jaffrelot, C. 2017. India in 2016: Assessing Modi Mid-Term. Asian Survey 57(1): 21-32.

Jha, P.S. 2017. China-India Relations under Modi: Playing with Fire. China Report 53(2): 158-171.

Karnad, B. 2018. Staggering Forward: Narendra Modi and India's Global Ambition. New Delhi: Penguin Viking.

Mattoo, A., and H. Jacob, eds. 2010. Shaping India's Foreign Policy: People, Politics and Places. New Delhi: Har-Anand.

Mazumdar, A. 2017. Narendra Modi's Pakistan Policy: A Case of Old Wine in Old Bottles. The Round Table: The Commonwealth Journal of International Affairs 106(1): 37-46.

Mohan, C.R. 2015. Modi's World: Expanding India's Sphere of Influence. New Delhi: HarperCollins.

Ogden, C. 2018. Tone Shift: India's Dominant Foreign Policy Aims under Modi. Indian Politics and Policy 1(1): 2-23.

Pant, H.V. 2019. Indian Foreign Policy: The Modi Era. New Delhi: Har-Anand.

Pant, H.V., and A. Rej. 2018. Is India Ready for the Indo-Pacific? The Washington Quarterly 41(2): 47-61.

Pant, H.V., and Y. Joshi. 2017. Indo-US Relations under Modi: The Strategic Logic Underlying the Embrace. International Affairs 93(1): 133-146.

Plagemann, J., and S. Destradi. 2019. Populism and Foreign Policy: The Case of India. Foreign Policy Analysis 15(2): 283-301.

Rajagopalan, R. 2020. Evasive Balancing: India's Unviable Indo-Pacific Strategy. International Affairs 96(1): 75-93.

Singh, S., ed. 2017. Modi and the World: (Re)Constructing Indian Foreign Policy. Singapore: World Scientific.

Tellis, A.J. 2016. India as a Leading Power. Washington: Carnegie Endowment for International Peace.

Tellis, A.J. 2018. Narendra Modi and US-India Relations. In Making of New India: Transformation under the Modi Government, ed. B. Debroy, A. Ganguly, and K. Desai, 525-535. New Delhi: Wisdom Tree.

Tharoor, S. 2018. The Paradoxical Prime Minister: Narendra Modi and His India. New Delhi: Aleph.

Tremblay, R.C., and A. Kapur. 2017. Modi's Foreign Policy. New Delhi: Sage.

Wojczewski, T. 2020. Populism, Hindu Nationalism, and Foreign Policy in India: The Politics of Representing 'The People' International Studies Review 22 (3): 396-422.

Publisher's Note Springer Nature remains neutral with regard to jurisdictional claims in published maps and institutional affiliations. 